\title{
Vocational Decision Making and Anxiety during the Coronavirus 19 Pandemic
}

\section{Toma de decisión vocacional y ansiedad durante la pandemia de coronavirus 19}

\author{
LOZANO-GUTIÉRREZ, Jorge Luis $\dagger^{*}$, PACHECO-AMIGO, Beatriz Mabel, SOLÍS-RECÉNDEZ, \\ Emma Perla and RODRÍGUEZ-GARCÍA, Francisco Javier
}

Universidad Autónoma de Zacatecas. Unidad Académica de Psicología

ID $1^{\text {st }}$ Author: Jorge Luis, Lozano-Gutiérrez / ORC ID: 0000-0001-7294-2572, Researcher ID Thomson: P-8291-2016, CVU CONACYT ID: 947027

ID $1^{\text {st }}$ Co-author: Beatriz Mabel, Pacheco-Amigo / ORC ID: 0000-0002-8053-3506, Researcher ID Thomson: P-7758-2016, CVU CONACYT ID: 514725

ID $2^{\text {nd }}$ Co-author: Emma Perla, Solís-Recéndez / ORC ID: 0000-0002-1074-9811, Researcher ID Thomson: S-6705-2018

ID $3^{\text {rd }}$ Co-author: Francisco Javier, Rodríguez-García / ORC ID: 0000-0002-8286-7694, Researcher ID Thomson: S-66832018, CVU CONACYT ID: 947161

DOI: $10.35429 / J U P .2021 .14 .5 .13 .18$

Received July 10, 2021; Accepted September 28, 2021

\begin{abstract}
Vocational decision making and anxiety during the coronavirus pandemic. The objective of this research is to identify the relationship between vocational decision making and anxiety during the coronavirus pandemic. The study is descriptive, cross-sectional, non-experimental, correlational. The study subjects are high school students who are at the time of making a vocational decision. The students were selected using the snowball technique since they were not in the classrooms of educational institutions during the semester period from January to July 2021. The variables of the study are vocational decision-making and anxiety in times of coronavirus pandemic. The reliability of the evaluation instruments such as the Herrera and Montes Interests and Aptitudes Questionnaire and the Beck anxiety test were obtained. Locating the correlation between the variables. The SPSS statistical package was used for data analysis. The obtained results, in terms of the reliability of the instruments that place them on a Cronbach's Alpha, are between .8 and .9 each of them. The main conclusion is that the relationship between anxiety and vocational decision is not important for vocational decision making since anxiety during the coronavirus pandemic does not affect vocational decision.
\end{abstract}

Vocational decision making, Anxiety, Coronavirus pandemic

\begin{abstract}
Resumen
El Objetivo de la presente investigación es identificar la relación entre la toma de decisión vocacional y la ansiedad ante la pandemia del coronavirus. El estudio es de tipo descriptivo, transversal, no experimental, correlacional. Los sujetos de estudio son alumnos de nivel medio superior que están en el momento de tomar una decisión vocacional. Los alumnos fueron seleccionados por medio de la técnica bola de nieve ya que no se encontraban en las aulas de las instituciones educativas durante el periodo del semestre de enero a julio de 2021. Las variables del estudio son la toma de decisión vocacional y la ansiedad en tiempos de pandemia del coronavirus. Se obtuvo la confiabilidad de los instrumentos de evaluación como es el Cuestionario de Intereses y Aptitudes de Herrera y Montes y la prueba de ansiedad de Beck. Ubicando la correlación entre las variables. Se utilizó el paquete estadístico SPSS para el análisis de los datos. Los resultados obtenidos, en cuanto a la confiabilidad de los instrumentos que los sitúan en un Alpha de Cronbach, están entre .8 y .9 cada uno de ellos. La conclusión principal es que la relación entre ansiedad y decisión vocacional no es importante para la toma de decisión vocacional ya que la ansiedad durante la pandemia del coronavirus 19 no afecta la decisión vocacional.
\end{abstract}

Toma de decisión vocacional, Ansiedad, Pandemia de coronavirus

Citation: LOZANO-GUTIÉRREZ, Jorge Luis, PACHECO-AMIGO, Beatriz Mabel, SOLÍS-RECÉNDEZ, Emma Perla and RODRÍGUEZ-GARCÍA, Francisco Javier. Vocational Decision Making and Anxiety during the Coronavirus 19 Pandemic. Journal of University Policies. 2021. 5-14: 13-18

\footnotetext{
* Correspondence to Author (email: jorgeluis_lic@ @otmail.com)

$\dagger$ Researcher contributing as first author.
} 


\section{Introduction}

Addressing the issue of vocational decisionmaking and anxiety during the coronavirus 19 pandemic is important. Students from educational institutions within their evolutionary development present crises in various stages, one of those crises occurs in a period where they must choose professional career, a crisis that can be aggravated by the presence of the coronavirus 19 pandemic in the face of policies for its containment. Identifying the relationship that occurs in decision-making and the impact of anxiety will offer possibilities to develop coping strategies for students and that, in the face of this risk situation and other similar ones, they have established ways to reduce the harmful effects of the pandemic in a vocational decision.

The central hypothesis of this research is that anxiety coming from the coronavirus 19 pandemic influences the vocational decision of upper secondary school students.

The development of this work is carried out in three theoretical sections where the issue of vocational decision will be addressed, later the anxiety in the vocational choice and finally the vocational decision and the coronavirus 19 pandemic, The methodology, presentation of results and conclusions.

\section{The vocational decision}

Within the evolutionary development, people face different situations that lead them to take decisions. Among these decisions are those of a vocational nature. They are important because they involve psychological processes that involve life projects; therefore, they are fundamental in the construction of the student's future, mainly of those who are in the stage of deciding the direction of their career that will lead them to a profession that will allow them to adjust to the world of work with their personal characteristics.

The decision is defined as a "voluntary act, choice that follows conscious and reflective deliberation" Dictionary of Educational Sciences (1996). This voluntary, conscious, and deliberative deliberation must lead to a decision making. Decision making "is a special type of problem solving in which we already know all the possible solutions or options.
The task is not to find new solutions, but rather to identify the best available solution, or the option that is closest to meeting our needs and goals. " Morris and Maisto (2011).

The vocational decision in adolescents is one of the actions that presents a great tension since it shows little certainty of the different factors that must be taken into account to arrive at the vocational choice that allows them to pursue a career. Rivas (1998) understands career as the "sequence of positions held by a specific person through their pre-professional, professional and post-professional life". Thus, the development of vocational behavior that already comes from the family is taken from the context of the educational system. Vocational behavior occurs in "a dialectical relationship between the person and the socio-professional environment that signals the culmination of the evolutionary process of socialization of the human being in their productive environment" Rivas (1998).

The vocational process begins from the socialization in the family through the school as one of the institutions that will be in charge of bringing the training that will culminate in the integration of its graduates into the productive labor system in accordance with the requirements of the world of work. The most satisfactory way to carry out the vocational decision-making process is the adaptation of the individual's personal characteristics to the characteristics of the world of work.

Getting to choose a profession contains the execution of psychological processes that will allow involvement in work environments. From a vocational developmental perspective, the adolescent goes through various periods in vocational behavior that depend on spatialtemporal situations that go from childhood, through play, to the formalization of professional activity in adulthood. According to Ginzberg in Rivas (1998) there are three periods: 1. Fantastic period that goes from birth to 11 or 12 years. 2 . The tentative period ranging from 11 to 17 years old. 3. Realistic period that goes from the 18 years to the twenties (approximately between the 24 to 25 years). The period in which the adolescent must make vocational decisions and presents a critical stage due to the adolescent's development conditions is the trial period, where the adolescent is located within the upper middle level in the school system and in a situation of vocational choice.

LOZANO-GUTIÉRREZ, Jorge Luis, PACHECO-AMIGO, Beatriz Mabel, SOLÍS-RECÉNDEZ, Emma Perla and RODRÍGUEZ-GARCÍA, Francisco Javier. Vocational Decision Making and Anxiety during the Coronavirus 19 Pandemic. Journal of University Policies. 2021 
To make this choice, the adolescent's personal factors are combined, such as their vocation expressed in their interests, their aptitudes, the personal identity that is achieved through the adaptation of the various social roles and the occupational identity. Regarding the intervening social factors, as the genetic load of parents heritage, heritage is involved, the relationships at home, family values, the perception of professions, the culture and the environmental context, the economic situation. All the above factors will take the adolescent to a vocational choice.

\section{Vocational choice anxiety}

Finding a vocational decision is not an automatic and easy process to obtain, perhaps some adolescents do not go through a critical situation for making vocational decisions and they go without any problem until they enter the world of work. For Bohoslavsky (1974), psychoprophylaxis is "any activity that, from a level of psychological analysis and through the use of psychological resources and techniques, tends to promote the development of the human being's possibilities, the maturity as an individual and, ultimately, his happiness". It is about promoting the prevention of health in general and not only the mental health. In this prevention, "the participation of the psychologist in the face of problems that create anxiety in specific moments or periods of life: sexuality, professional orientation, job choice, etc." is found.

The factors that intervene in the vocational decision in general can be divided into two main areas, the sociological-based approaches and the individual-based ones, according to Rivas (1998) mentions the characteristics of each one. Sociologically based ones have to do with home, community, environmental pressures, socio-professional status, information and knowledge of professional roles, and rapid technological and social changes. In the individual factors, vocational behavior is directed to selfrealization. It is a gradual and accumulative process organized in experiences, it leads to autonomy and personal commitment, it is multipotential in the vocation. The key to making the most successful vocational decision for students is to combine self-knowledge, the social factors involved, and knowledge of the world of work to which they will be incorporated.
Anxiety is present in this critical decision-making stage. When the person is able to overcome that anxiety with his own resources, he will carry out a process that will allow to prevent negative repercussions on the student's general health, both psychologically and physically. But in the event that anxiety blocks the ability to make that vocational decision, it will be necessary to go to vocational counseling, where it will be identified and deepened through a vocational counseling process aimed at obtaining a vocational decision.

Anxiety can be defined as an anticipatory response to future harm or misfortune, accompanied by a feeling of unpleasant dysphoria, somatic symptoms of tension or avoidance behaviors (Ministry of Health and Consumer Affairs, 2008). Anxiety can present various signs and symptoms which can be a feeling of nervousness, agitation or tension, a feeling of imminent danger, panic or catastrophe, increased heart rate, rapid breathing, sweating, tremors, feeling weak or tired, trouble concentrating or to think about something other than the current concern, having trouble falling asleep, suffering from gastrointestinal problems, having difficulty controlling worries, having the need to avoid situations that generate anxiety.

\section{The vocational decision and coronavirus pandemic 19}

One of the external factors that have strongly impacted the development and course of social interrelations in the global context has been the pandemic due to covid 19. The data obtained from the United Nations (UN) until October 25, 2021, are the next. In the world: 242688319 confirmed cases 4932928 deaths and 6655399 359 doses of vaccine applied. In Mexico: 3783 327 total cases, 286346 deaths and 115185985 doses of applied vaccines reported (UN Mexico, 2021).

Educational institutions have not been the exception, on the contrary, the restrictions carried out by the authorities of all levels of government to combat the pandemic began in the area of education and were among the last institutions that took action to move to the normal. Schools, despite the difficulties that have arisen, have carried out their work virtually with digital technologies offered by current technological advances. 
According to the research by Paredes and Gómez (2020) in which they deal with anxiety and depression in university students during the pandemic, in their conclusions $66.7 \%$ responded that from time to time they feel tense or nervous, which indicates the existence of anxiety in students.

The activities related to vocational guidance from educational institutions have continued to be implemented by adapting to social, health, educational conditions, and the vocational counseling itself. Higher-level educational institutions have followed their selection and acceptance processes for their new members through the educational offer available at times of vocational decision and selection of professional career options. Actions have been implemented so that the students of upper secondary education who are in the stage make a vocational decision.

There have been offered various activities such as the ExpoOrienta, which is an academic event that brings together various public and private educational institutions. They show their educational offerings. Upper secondary level students have the opportunity to know, understand, analyze and compare the different options that will allow them to decide their life project in the professional field. There are other options so that students can get to know themselves by also offering them tools that help to achieve that self-knowledge.

In this way, the student is offered a possibility of knowing himself as their interests, aptitudes, abilities, motivations, personal potentialities and likewise the knowledge of the professions and the world of work to which they will enter in the future through of an adjustment of the personal and social aspects with the characteristics of the labor world to which they must enter.

Even with all this set of elements that are offered, the student may experience symptoms of anxiety and at a given moment a blockage may appear in the ability to choose a vocational option or to overcome that anxiety and reach a vocational decision.

\section{Methodology}

The research is quantitative, not experimental, descriptive. It was carried out with students belonging to various educational institutions in the State of Zacatecas. A total of 66 students participated. The selection of the students was by the snowball technique since they were not in face-to-face classes and the instruments were applied in person. The general objective of the research is to identify the trend in the vocational decision and the anxiety level of the upper secondary level students.

The hypothesis is that anxiety in times of the Covid 19 pandemic influences a trend in the vocational decision of high school students. To identify the trend in the vocational decision, the Herrera and Montes questionnaire on interests and aptitudes was used. It has 60 questions for interest and 60 questions for aptitudes.

With a Likert-type scale, the options were: a lot, pretty much, indifferent, a little and nothing. With a value of 4, 3, 2, 1 and 0 points respectively. It has 10 areas: 1) Social Service (SS), 2) Persuasive Executive (EP), 3) Verbal (V), 4) Plastic Artistic (AP), 5) Musical Artistic (AM), 6) Organizational (ORG), 7) Scientific (CT), 8) Calculus ( $\mathrm{Cl}), 9$ ) Mechanical (MC), and 10) Outdoors (AL).

Scores were obtained according to the scales established in the questionnaire. The Beck II Anxiety questionnaire consists of 21 items with a Likert-type scale, the options being 4 statements that are scored 0,1,2 and 3 according to the option selected. The obtained result is the level of anxiety that can be low, medium and high.

\section{Results}

The results are presented by means of comparative graphs and tables that were obtained through the applied tests.

Regarding interests and aptitudes 
Interests and Skills

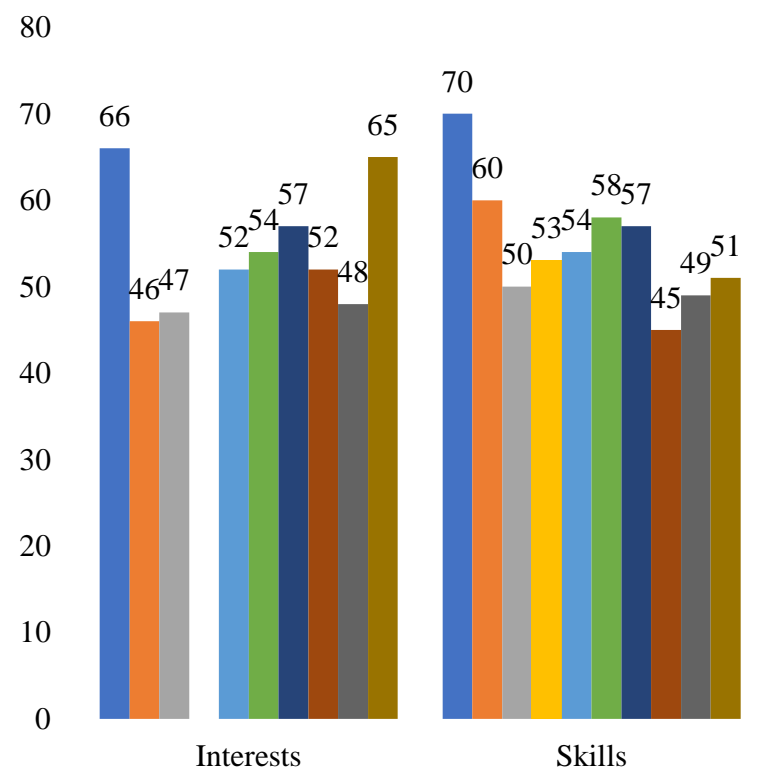

Graph 1 Interests and Skills. The percentage is shown in each area

\begin{tabular}{|l|r|r|}
\hline \multicolumn{1}{|c|}{ Area } & $\begin{array}{c}\text { Interests } \\
\text { Centile }\end{array}$ & $\begin{array}{c}\text { Skills } \\
\text { Centile }\end{array}$ \\
\hline Social Service & 66 & 70 \\
\hline Persuasive Executive & 46 & 60 \\
\hline Verbal & 47 & 50 \\
\hline Artistic Plastic & 57 & 53 \\
\hline Artistic musical & 52 & 54 \\
\hline Organizational & 54 & 58 \\
\hline Scientist & 57 & 57 \\
\hline Calculus & 52 & 45 \\
\hline Mechanical & 48 & 49 \\
\hline Outdoors & 65 & 51 \\
\hline
\end{tabular}

Table 1 Comparative in percentages of vocational areas

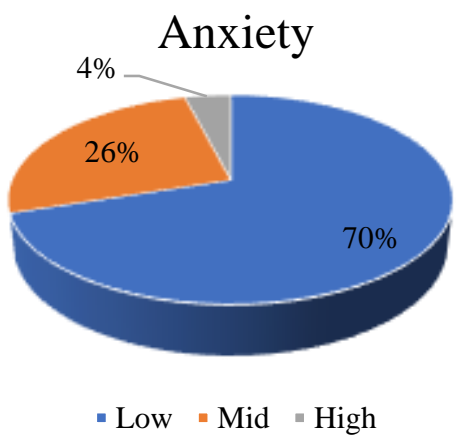

Graph 2 Anxiety levels presented by the students of the upper secondary level

Regarding the reliability of the tests applied through Cronbach's Alpha coefficient, the following table is presented:

\begin{tabular}{|l|r|}
\hline \multicolumn{1}{|c|}{ Test } & Cronbach's Alpha \\
\hline Anxiety & .86 \\
\hline Interests & .92 \\
\hline Skills & .91 \\
\hline
\end{tabular}

Table 2 Reliability of the instruments used in the research

\section{Conclusions}

The used instruments have a reliability located in excellent since they have a score between .86 and 92. The area of vocational trends with the highest choice was that of social service, both in interests and aptitudes with a percentage of 66 and 70 respectively. The second area in interests was outdoors with a percentage of 65 and the persuasive executive area in skills with a percentage of 60.

Regarding anxiety, they were placed as follows: Low 70 percent, medium 26 percent and high with four percent. According to these results, the hypothesis is rejected since the high school students who have to make their vocational decision do not present significantly high levels of anxiety during the Covid 19 pandemic.

\section{References}

Bohoslavsky, Rodolfo (1974) Orientación vocacional: La estrategia clínica. España. Editorial Nueva Visión.

Diccionario de la Ciencias de la Educación (1996) Tercera reimpresión. Madrid. Editorial Santillana.

Ministerio de Salud y Consumo Grupo de Trabajo de la Guía de Práctica (2008) Clínica para el Manejo de Pacientes con Trastornos de Ansiedad en Atención Primaria. Madrid: Plan Nacional para el SNS del MSC. Unidad de Evaluación de Tecnologías Sanitarias. Agencia Laín Entralgo. Comunidad de Madrid. Guías de Práctica Clínica en el SNS: UETS N²006/10.

Morris, Charles G. y Maisto, Albert A. (2011) Introducción a la psicología. 13a . Edición. México.

Organización de las Naciones Unidas (2021) COVID-19. Información Oficial de las Naciones Unidas. https://coronavirus.onu.org.mx/

LOZANO-GUTIÉRREZ, Jorge Luis, PACHECO-AMIGO, Beatriz Mabel, SOLÍS-RECÉNDEZ, Emma Perla and RODRÍGUEZ-GARCÍA, Francisco Javier. Vocational Decision Making and Anxiety during the Coronavirus 19 Pandemic. Journal of University Policies. 2021 
Paredes Prada, E. T., \& Gómez Gómez, E. L. (2020). Evaluación de la calidad de vida, depresión y ansiedad en estudiantes de decimo semestre del programa de Profesional en Actividad física y deporte de la Facultad de Ciencias Socioeconómicas y Empresariales (FCSE) de las Unidades Tecnológicas de Santander (UTS) durante la pandemia COVID19. Facultad de ciencias socioeconómicas y empresariales Profesional en actividad física y deporte. Bucaramanga. 15 de diciembre de 2020

Rivas, Francisco (1998) Psicología vocacional: Enfoques del asesoramiento. Tercera edición. Madrid. Editorial Morata. 